\title{
International Law under Queen Elizabeth
}

THE latter part of the reign of Elizabeth ras, in tho political 1 and religions world, an age of premonitions. Most of the great questions in church and state which were to be the sabject of the long struggle of the seventeenth century emerged as problems demanding solntion before the close of the eirteenth. Among these it is of interest to note that forty years earlier than the "limit of legal memory' in international law, the publication in 1624 of Groting's De Iure Belli et Pacis, Elisabeth and her ministers were diecussing with the governments of Spain, the Hanse towns, the Netherland8, Denmark, Polsnd, and France the freedom of the seas, the position and privileges of ambassadors, the neages of war, contrabend, and the rights and duties of neutrals.

Most of these disputes grew directly or indirectly out of the troubled relations betrean England and Spain. At five periods betreen 1580, when hostility between the two countries first became sonte, and the desth of Elisabeth, in 1608, questions of international law rose into special prominence. In September 1580, when Drake returned from his voyage round the world, bringing with him a store of plunder captured from Spanish settlemente and vessels on the cosets of Bonth America, Mendoza, the ambessador of Bpain in England, appealed directly to Elizabeth for the restoration of the stolen property. No immediate reply or direct satisfaction was given to bim, a permonal interview with the queen being postponed on one ground after enother for almost a year, and complsinte of the misdeeds of the Spaniards in Ireland being mede to serve in the place of explanstions of those of Drake in America Indeed, no official ansper had been made when diplomatic relations were finally broken off three years afterpards. The questions involved hed been, however, the sabject of mach discassion ; frequent unofficial communications were made to Mendora, and at one time a formal reply which hed been dramn up by the privy conneil, and was only awaiting the production of a fair copy, was promised to him by Walaingham, but subsequantly 
stated to have been lost. Tro skilfal formulations of the points at issue still exist. ${ }^{1}$ Berides these Comden, the contemporary annalust, who had access to offcial papers, preserves a reply to the Spaniards which is either the peper drawn ap by the privy council and afterwards lost or suppresed, or the substance of the verbel statements made to the ambaseador, or some later com. manication. This reply points out that Drake is subject to prosecution in the English courts by the ambasesdor or by any one elee whom he has wronged, and promises that, if he is proved to have done snything illegal, restitution will be made from the treseure he has brought home with him. The English position is then stated as follows :-

The Spanierde leve brought these evilg on themselves by their injustioe towards the Englinh, whom, contra itu gontsum, they have excladed from commerce with the West Indies. The queen does not acknopledge that her subjects and those of other nations may be excluded from the Indies on the olem thet these have been donated to the hang of Bpain by the pope, whose authority to invest the Spaninh king with the Now World es with a flef the does not recogniev. The Speniarde here no alem to property there except that they have established a for mettlemente and named rivers and capes. This donetion of phat does not belong to the donar and this imeginary right of property ought not to prevent other princes from carrying on commerce in thowe regions or establishing colonies there in places not whabited by the Spaniarde. Such action would in no way violate the lar of astione, since prescription without posession is not valid. Moreorer all sire at liberty to nerigate thet vast ocean, sinoe the use of the ses and the air are common to all. No nation or private pereon can here a right to the ocean, for neither the course of nature nor public anafe permite any occupation of it.'

Thus on the first occasion when a serions dispute arose es to the Spanish monopoly of the Indies Elisabeth asserted the freedom of the seas. This assertion was besed alike on nature and the iws gentium, and from it was deduced the claim that all nations hed the right of navigation, trade, and colonigation in all seas and lands, limited only by the actaal occupation of those landa by another civilised power.

The ralations between England and Spain became more and more strained, from a variety of canses, until early in 1584 they reached a crisis, when Mendoza wes charged on the confession of Throckmorton, the conspirator, with heving taken part in the plot for the liberation of Mary and the deponition of Elizabeth. The English government was inclined to execute or imprison the mbassador, some of the members of the council arging that 'in

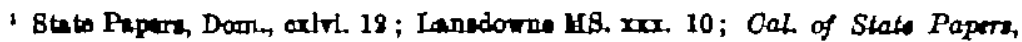
Spanish, 1680-0, po 50-01, 249, 128.

- Cemdon, Arrales, 2 a 1000, p. 800 (od 1600). 
vaine he putteth himselfe ander the afeguard of nations which violateth the lawe of nations.' But before taking action they consalted the two best known teachers of civil law of the time, Albericus Gentilis, then lecturing at Orford, and the French jurist Hotman. These both advised that, although perhape a more severe punishment might be abed, it was preferable that he should be merely expelled from the country. This advice was accepted, and in a otormy sceme before the privy conncil the ambeseador replied to the ourt orders from Walaingham for his departure within fifteen deys with hanghty defiance, threats of war, and an appeal to his own sovereign for judgment upon his actions. Within a few days he sailed from Dover. With the object of postponing a definite breach with Spain Elizabeth sent, close on the heels of Mendoza, William Wead, one of the secretaries of the privy conncil, with instructions to give the king a fall explanation of the canees for the expulaion of his ambasador. Philip refused to see Waad, and referred him to his secretary and council. Bat Wead declined to give to them an explanation which was intended for the king in person, and after an unofficial intervier with Idiaques, the secretary, who treated the matter somewhat lightly, returned to England, with bis letters andelivered and his mission anperformed. Indeed some were surprised that he retarned enfely at all, for it was anknowledged that 'ho carried bitter atuff.' This incident of 1584, like that of 1580 , was closed without any agreement having been reached. Nor as a precedent was the action of the government definitive, for the degree of privilege of an ambarsador long remained quite oncertain. It did, however, attract the attention of stadents to the question involved, and at the annual dispatations at Oxford in the succoeding summer, at which Leicester and Sidney were present, Gentilis made this the subject of his address. His work Do Legationibus was published the next year, end one of its fallest chspters is devoted to the question, $S i$ logatue in principem coniurazorit apud quem legatus est. In this he describes the incident of 1584 and refers to natare as the baris of internstional law, just as Elisabeth and her counsellors hed done in 1580 . Habet ites gentium rationes naturales quae, insitas omnilus a ratura, sic notas sunt ut argtinento mullo indigeant, nullaque, quibus adprobeniur, arte.

The most important questions of international low under Elizabeth, however, arose in connexion with the Armada sent againat

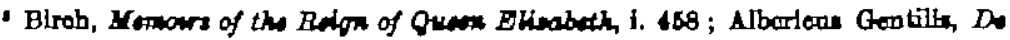

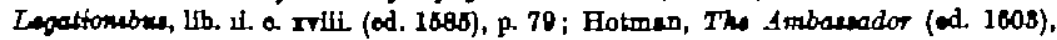
pp. 10:-6; Cal. of State Papere, Bpenilu, 1000-6, pp. 518-6; Col of State Papers,

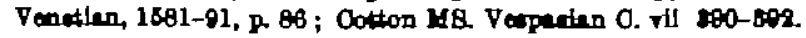

- De Lepationibes, lib. H. a xrili. ; T. R. Hollend, Inougural Lectwre at Otford, 1874 ; Coke, Fowrth Inetitute, p. 158.
} 
England by the Spaniards in 1588 , and in that year were laid the beses of the policy which her government asserted daring the whole remeinder of her reign. The money resonrces of Spain were great. She received rest amounte of silver and gold from her Ameriean posseseions and much valuable merchendige from the East Indies;--but the was very insufficiently provided with the immediate requirements for war. For materials for the building and equipment of abips, for ammunition, for food staffs she was largely dependent on other countries. Burleigh declared, 'It hath bene in all former tymes known, and is notably known to all persons that hannt the navigation and cost of Spayn thet without havgng of masts, boords, cabals, cordeg, pitch, tarr, and copar out of the Eastlanda, all Spayn is not hable to make a navy redy to carry the meaneet army that can be ymagined.' After the ontbreak of hostilities, therefore, it became a settled polioy on the part of Englend to weaken Spain by keeping from her, as far as possible, all such foreign supplies.' Nevertbeless the Armads, in 1588, was largely equipped with food, navel stores, and ordnence by the merchants of Hamburg, Lübock, Dantrig, and other Hanвe towns; and eeveral of the largest veseels of the 8panish feet were bought from the Hansards. Coneequently in November of that year, at the command of the queen, the privy council summoned before them Marice Timberman, alderman of the Btealyard, who was looked upon as in a certain sense the resident representative of the Hanse town, and throngh him sent to them a vigorous protest against this unfriendly action, as the council termed it. Moreover they demanded that he should write letters to the Hanse cities requiring them

to forbeare to sand into Bpain or Portagal any hind of provision flt for the mentensnos of the kfog of Speyne for his warres afrainst this realm, upon peine of conflecation of the same gooden and the shippes apon which they should be leden, in oses they shoold be taken with any soch warlyke provision by any of her majestid's shippes or of her subjects."

The aldermen was sufficiently impreseed with the demend to reduce it to writing for the inspection and approval of the conncil, and then transmitted it to the parties concerned. When an ambaseador from Hamburg arrived in London ahortly aftorwards, the council gave the anme warning to him, and a little later proved the seriousness of their intentions by stopping and examining the contents of some Hanse veeels off the port of Dover. Instructions were at the same time inserted in the commisaion of Drake and Norrie, who were about to set sail with the 'Connter-

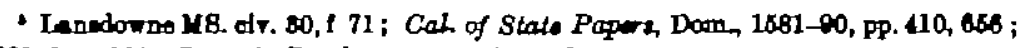
1001-8, p. 101; Dymon's Proclematrome, 296, 851.

- B. P. Dam, Blis oxxv. 18 ; Lanedowno MR. dr. $80, t 71$. 
Armada ' of 1589, to eire any warlike goods intended for Spain found in neatral ressels.'

Notwithstanding the intimations given to them in these various ways, the Hanse merchants were not willing to forego the profitable sale of eupplies to Spain ; and in order to reach thet tempting market and at the same time to avoid meeting English ships, a fleet of veesels from Baltic and North Ses porte mede the long and dangerons voyege round the Orkneya, Hebrides, and Ireland. On 80 Jane 1589 they sailed into the harbour of Cascais, at the mouth of the Tague, just as the victorious English fleet was about to leave it after gacking the anburbe of Liebon. The German hulks, es such freight veseels were called, were laden with whest, rye, cheese, max, canvas, and other such goode, and slthough eleven, one of which was rigged as a warahip for sale to the king of Spain, escaped, eome sirty were captured by the English and carriod away with them to Plymouth, Portomonth, Southampton, Deptford, and other English ports. On 87 July the privy conacil issued a formal decree reciting the facts of the previous warning, and of the discovery and seisure of the contrabend articles, and justifying by the torms of their treaties and by 'the laws of netions ' the confiscation of all the ships with their cargoes. At the same time, by the special grace and favour of the queen, they ordered that only 'such things as were laden in any of the said shipps which are manifestly of the proper nature of victualle and of manitions, as particularly sett downe in the foote of this decree,' should be confiscated to the queen's use. The 'note of such things as are thonght good to be stayed ' which follows is probably the esrliest recorded list of articles declared contraband, and as sach is printed here in fall.

Monttione.

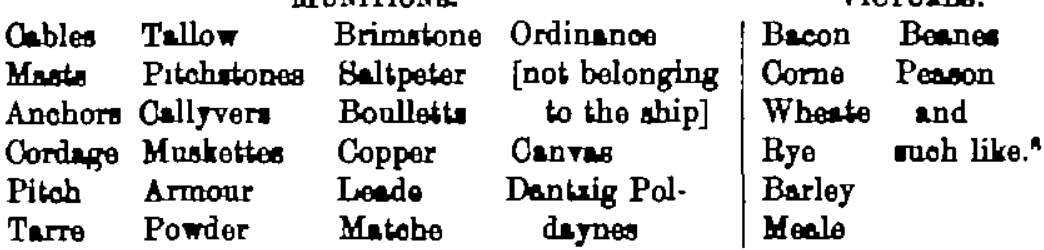

The council was much occupied daring the ensaing months in providing for the sale of the seised goode and the restoration of

1 B. P. Dom, Blix. corrii. 86, 69; $000 \mathrm{dill}$ 64.

- The enmo poliey we epplied to other nations as to the Henas towne On 90 Nov. 1688 Btr Thomas Bodley, the Engllinh embenedor to the Netheriende, wa In.

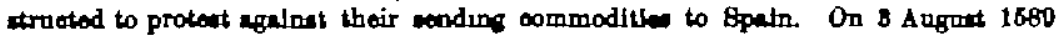
the privg oonnell gare orden to the Engtieh emberendor in Hollend to demand that oertein shlps thet were londing in Hollend and Zeatand with grain sopponed to be for

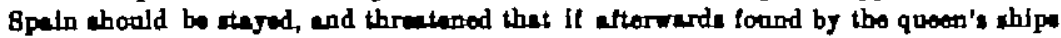

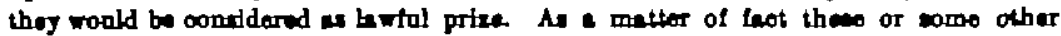

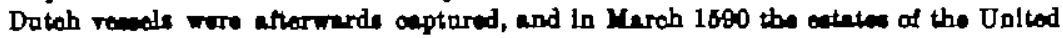


the ships, and in answering the expostalations of the shipmasters and merchants of Hambarg, Lübeck, Dantsig, and Wismar. A formal protest of the Hange government was made on the characteristic but somewhat ill-chosen ground thet the seisures were against their ancient privleges in England. The English government, in its answer, easily met them on their own ground by pointing ont that the Carta Mercatoria of 81 Edward I, on which their trade in England was based, had been granted on the exprese condition that foreign traders coming into England should not carry any commodities into the dominions of the professed enemies of England. A long series of precedents was next adduced. In 1645, in the war between England and France, Hanse vessels which were taking sapplies to the latter had been soired by England, and Charles V had acknowledged the justico of the seixure and forced the Hensards to respect neatrality. In the recent war between Bweden and Denmark neatral trade had been prohibited. In the mar between Poland and Muscovy the same rights had been enforced by Poland against England hereelf; and quite recently the prince of Orange had insisted on the eame right of seisore of contraband againgt the Hansards and others. $\Delta$ broad statement of principle is nest made. "These precedents are just, for the right of neatrality must be ased in such a ray thet none in our alliance are injured. It is not rightfully ased when by helping one ally we are injaring another who is equally in our alliance.' The queen and her councillors seem to hare felt the matter important enough to be given the greatest pablicity. Burleigh drew up a proclamation 'for the satisfaction of euch as are cepsule of resson and void of malyce,' in which he states the claim of the government in the brodest ray.

Her Hajenty thynketh and knoweth it by the rules of the law as rell of neture as of men, end epecielly by the low civil, that whenever any doth dirootly help her enemy with sucoours of eny victell, armor, or any lynd of munition to onbablo his shippes to meintein themsel ree, the may lavfully intorrapt the ame, and this agreeth with the law of God, the ler of nature, the lew of nation, and hath been in all tymes practinod and in all coontriea betryst prynce and pronee, and country and country.

Provinese compleined loodly, and asked thet their ordinery tredo with Bpain whonld not be interfored with. 8. P., Dom., Eliz cexrv. 11; Cal of State Pupure, Dorn,

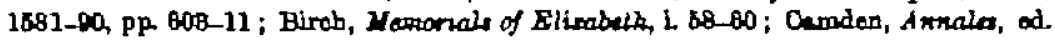
1617, ii 11; Oppanbolm, notos to Momen's Tracts (Nary Reoords Boctety, 1902), pp. $272-6$.

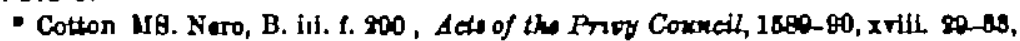

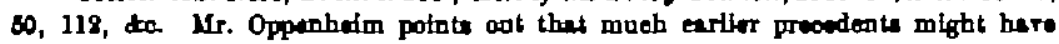
been found by the ouncll (note to Honson's Tracts, Nevy Record" Boon 1908, Fp. $978-6)$.

- Landown MS ar. 80, t. 70. 
$\Delta$ well-written and moderato pamphlet was also ispued in English and in Latin in August 1688, composed probebly by Burleigh and printed by the queen's printers, stating the English case before Earope. Similarly on 13 July 1589 in the propositions for alliance with the king of France it is declared that 'her majesty desyreth yt he will earnestly probibit ye carriedge of any grain or other vittull into Spayne or Portugall.' "I The right to seize enemies' goods in neutral ships seems to have been erercised whenever there wes an opportanity, and to have been so completely acquiesced in as to have raised no protest or discassion, for when the earl of Camberland and other English captains made a namber of seisures of Spanish and Portugaeso goods from Hanse and Datch vessels we hear of it only from the English side."

Thus within the years 1588 and 1589 the right of conflseation of contraband and enemies' goode was aseerted, enforced, defined, and defended, and daring the whole remainder of Elizabeth's reign was anstished part of the policy of her government. The contemporary records of this period, both English and foreign, are filled with instances of seirure, and with the conflicts that arose out of these, often complicated, it is true, with other matters in dispute between England and the continental statea. There was one time, eome six yeare after the disputes of 1588-89, when England's claims were made with such special distinctness and opposed with such vigour as to require separate mention. Early in 1596, when an Engliah fleet had been prepared for an atteck upon the shipe and coasts of Bpain and Portugal, a proclamation wes drawn up by the council, and on 24 April issued in the nemee and under the eeals of the earl of Eseex and Lord Admiral Howard, the commanders of the expedition. It was translated and printed in English, French, Italian, German, and Spanish, and distributod as widely as possible in the seaports of Spain and Portagal. It declared that, England boing in amity with all nations eroept Spain, her majesty's navy had orders to refrain trom injury to the persons and property of all men, except, in the first place, subjects of the king of Bpain; in the second, such other persons as should give to that king 'menifest aid with men, shippes, artillery, victuals, and other warlike provisions for Invasion of her majesty.' All the latter class of persons were required to remore their ehips and contraband goods from all ports of Spain and Portugal. If they refused or neglected to do so, the commanders of the queen's navy would feel themselves at liberty to treat them as manifest aiders of the ling of Spain, and coneequently open enemies of England. They would, therefore, have

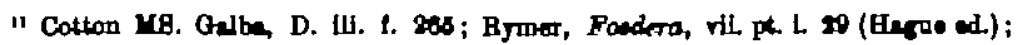
Lentowne M8. $104, \mathrm{t} .67 \mathrm{~b}$.

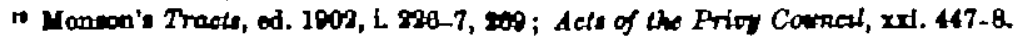


no just csuse of complaint or claim for restitation of such goods and ships as should be seized.

Engliah vesels in the narrow already had orders to stay all Easterling and Dutch vessels going southward, unless they had a pass from the lord admiral, and the privateers of the southern and vertern cosists were on the watch for such as should elude the government ahips. Frequent seisares followed. ${ }^{13}$ These and the prominence given to the matter by the proclamation of the admirals soon brought a response in the form of a series of proteste from other governments. Eerly in the summer of 1597 an ambasandor from Hambarg ceme to demand the restitution of cortain whest sent by Hanse merchants to Spain and intercepted by the English at They received from the privy council a reply on 24 Jone. Just a month later an embasay appeared from a new quarter. Among the Hanse cities which folt the hardsbip of English interference with neutral trade two, Dantrig and Elbing, lay in the dominions of the king of Poland, who at this time was the nerly elected Bigiomund. On 28 Jaly 1597 his anbassador, Paul Dzialin, a handsome, learned, and eloquent Polish nobleman, arrived in London. The first and only intervier of this ambessedor with the queen, occurring three days after his arrival, was a dramatic and amueing scene that has bean described for us by more than one eye-witness. Elizabeth's counsellors, mistaking the natare of his errand, informed her that he was probebly come to return thanks for certain favours the Engliah ambersador hed recently done Poland at the Turkish court. The queen, al ways glad of an occesion for display, and interested in what she had heserd of the ambesendor's personel sppearance, arranged a great reception for him on the occasion of his presentation. She sat under the cloth of state in the presence chamber at Greenwich Palace in the widet of a large body of the noblemen and gentlemen of her court. The ambessador pas ushered in, dressed in a robe of black velvet covered with jerels. He edvanced to the queen, kiesed her hand, then formally retired ten paces, and began in a loud voice a Latin oration which dumbfounded his hearers. After reminding the queen of the ancient alliance between the sovereigng of England and Poland he complained in the barshest terms that Elizabeth had enffered the subjects of his master to be despoiled, and with wanton injustice hed refased them reatitation, notrithstending repested petitions. She had taken upon herself, simply becanse she had a quarrel with the Spanish king, to issue a mandate cutting off all other people from intercourae with 8 pain

4 Bpeed, Ohromicle, it 808; Cat. of Slate Papers, 1608-7, pp. 173, 207, 219, 207, 184; 1508-1600, pp. 140-159, 160, 108, 477; Ach of the Proy Connoit, xx. 48;

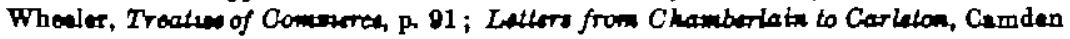
Bodaty, pp. 89, 88, 16, 119, 144, 172. 
and Portagal. In doing this ehe essumed to herself a superiority over other princes which was intolerable. The king of Poland, his master, was determined not to endure this, and if the queen would not reform it he would take measures to do so himself.

The moment his spech was finiahed Elizabeth, interrupting the lord chancellor, who was about to reply, answered the smbassador in en imprompta Latin address, which is reported in so nearly the eame words by several hearere that we doubtless bave it sub. stantially as ahe gave it. She cried out angrily, Oh quam decepta fui' Expectavi legationom, th vero querelam mihi adduxisti; per literas accepi te esse legatum, inveni heraldum. Nurquam in vita moa audixi talem orationem. Miror, sane miror tantam et tam ineolutam in pubtico audaciam. After declaring that if the king of Poland had sent such a message, which she did not believe, it mast be either becanse he was so young end inexperienced or else becanse he came to his throne by election and not by inheritance, like other princes, he proceoded, in words translated by a oontemporary-

And as for you, although I paroeive you have read many books to fortify your erguments in this cees, yet I am thin to believe you have not lighted apon the ohepter thet prescribeth the forms to be ased between lings and prinoes. Were it not for the plece you hold, to have so publiely thrown in impatation apon our jastice, which as jet never falled, we wonld enswer that andecity of youn in enother style. Binoe you have so often in your oration quoted the lew of netione you ought to know thet when war hes broken out between kings it is allowed to one party to interoept the ald or enocours sent to the other, and to provide thet no injury thenoe arive to himeolf. We declere that thes is in conformity to the $\mathrm{ker}$ of netare and of nations, and not enforced by as lone, bat by the kings of Polend and of Breden in the man which they heve raged with the Mascovite.

She referred the ambassador to her ministers for further reply to his protests, and closed with Valeas et quicscas. Then, as Speed вays, ' lionlike rising she daunted the malapert orator no lesse with ber stately port and majesticall departare than with the tartnes of her princelie checke.' Bofore leaving the room she turned half laughing to the gentlemen of the court and uxclaimed, with her favourite oath, 'God's desth, my lords, I have been enforced this day to seour ap my old Letin, thet hath lain long in rasting.' She endently proud of her speech, however, for she told Cecil she was sorry Esiser, who was then at Plymouth, had not been by to have heard her Latin, and she was pleased when Cocil promised to send him as much as he could remember of it.

A fer days afterwards four of the privy councillors repeated 
to the ambessador arguments that were practically the same as those Elizabeth had ased in her recent epech, and which must by this time have become tolerably familiar, an they were also those that had been ased constantly aince 1588 . They were, first, that the privileges which the Poligh, like other foreign merchants, posessed in England were given them on the express condition that they should not carry goods to the open enemies of England; eccondly, that the Englieh government had precedent for confiseation in the recent action of other conntries, and notably of Poland itself ; end, lestly, that to intercept succours sent to enemies ras in accordance with the law of nations, since it has been provided by natural lar that every one should defend himself. When the ambaseador was invited to give a reply to these argumente he declined, saying he was ent to deliver a message, not to mako responses, and so left England. ${ }^{14}$

The third embassy of the year in the same bosiness arrived a few weeks later. This was from Denmark. Two envoyg brought a protest against recent seirures, and a request that, 'if it stood with her majesty's good liking, the merchants of Denmark might transport their goods into Bpain without denger in the narrow seas, which heretofore some of them had sustained to their great loase.' By this time Elizabeth and her ministers were beginning to realise the necessity of walking somenhat warily. Apart from questions of contraband the old dispates betreen the English merchant adventarers and the Hanse towns were restricting English commerce. The discontent of the northern countries with the polioy of England was carefully fomented by Spain, and the possibility of their uniting with her in war againat England was not a remote one. ${ }^{14}$ Henry IV was already negotating that peace with Spain which made possible a policy of commercial development for France that oould ill brook the unlimited assertiveness of England on the beas. $\Delta$ somewhat more conciliatory policy with regard to contraband is therofore observable. Elizabeth replied moet mildly to the Denish ambassadors, declaring that she would investigate any case of molestation of Danish ships and give redress if there hed been injustice, and moreover pould make definite lawr against such molestation in the fotore. At the request of the ambasedors the English privy conncil drew up a ner list of 'prohibited' and ' licit' articles, agreeing that if the Danish king would order his eubjects not to carry any of the former goods to Spain during the war, the English naval commanders Foold be

14 Intter from Cocil to Besor, Cal. of 8tail Papara, 1695-7, pp. 172-6; Lentome M8. Iodv. 60; Cumdon, Axmalas, il 189; 8peod, Chromiclo, p. 871; Wheoter, Trantine of Conanore, pp. Br-110. ก1-2.

is Cal. of State Papers, 1k0k-7, pp. 600, 600; Hist MSS. Compr, Cwill MSg. vil. 
given orders not to interfere with those carrying the latter. The tro lists are as follow日 :

\begin{tabular}{|c|c|c|c|}
\hline \multicolumn{2}{|c|}{ Prohibitad Anticleg. } & & Liolt ABticheg. \\
\hline Cebles & Pitoh & Batter & Beanes \\
\hline ordege & Tarr & Ohoese & Iron \\
\hline Ganporder & Seltpeter & Bacon & Steole \\
\hline Hempe & Whent & Btockffish & Oopper \\
\hline Mestes & Rye & Pease & Rosin \\
\hline $\begin{array}{l}\text { Ordinence } \\
\text { Bailyard. }\end{array}$ & $\begin{array}{l}\text { Meale of wheet } \\
\text { or rye }\end{array}$ & & \\
\hline
\end{tabular}

She sent a special ambassador to the king of Poland, and through him, while reiterating her claim, iure gontium et citih, to configcate merchendise destined to her enemies, offered to pormit subjects of the king to transport freely into Spain grain and all kinds of merohandise except material for war. In 1599 a proclamation in favour of the commerce of Venice and Tuscany was issued against the exces of Englieh privateers going to the Mediterranean. Somewhat later, in September 1601, in the instructions given by Elizabeth's government to Bir Richard Leveson, along with the asual orders to seire all ships resorting to Spain with munitions, cordage, \&c., the reservetion is introduced that, 'considering these are chiefly brought trom the east conntries and not France, we forbid you to deal with French suljects except you soe pregnent canse; and then take hed that no spoil be committed.' Bir William Monson is carefully warned in the succoeding summer against any seirure or stay of vessels of her majesty's allies, anlese there is manifest proof of their carrying goods prohibited or belonging to sabject of the king of Spain."

Nevertheles the evidences of a conciliatory spirit ought not to be taken too seriously. Elizabeth and her ministers were far from surrendering their olaim to the right of contlacation of contraband. The queen's complacency to the Danish envoye and con. cessions offered to the Poliah cities only mede the list of contraband articles eomewhat narrower, without introdacing any change of principle. The care in exercising the right against France and the Italian states was rather directed to the avoidance of indefensible and embarrassing seisures then to a ceasation of the general policy. On the contrary, in a treaty for the restriction of reprisale entered into by England and France in 1600 it was specifically provided that no kind of arms or warlike ammanition shoald be transported by Frenchmen into the king of Spain's dominions, and in the last jear of Elizabeth's life the right was still being exercised, for in that year the French ambassedor was beard to declare that his government would no longer endure having their ships riewed by the

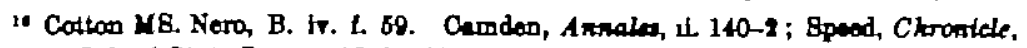
p. 871 ; Cal. of Stato Papors, 1090-1000, p. 168 ; 1601-s, pp. 101, 159, 920, 800. 
quean's ships. In the very negotiations with the Danish envoys in which Elirabeth had made such abondant promises of reatitation for lose the commiesioners were indaced, before they returned home, to agree ' that none of the king of Denmark's subjects should traneport, or cause to be transportod, any kind of those things whereby the Spanish king, being her mojesty's known enemy, might be fortified by land or gea against her majesty.' Two years latar, daring a renered effort to settle the verions disputes betreen England and Denmark, the English enroys suacessfully insisted on a new agreement ' that no warlike material should be carried into Spain,' notwithetanding the efforte of the Danes to exclade that point and their declarstion that their trade of no value to the Spaniarde, and did nothing to prolong the war. ${ }^{17}$

Elixsbeth's old contention for the freedom of the was renewed in 1602 with the same argamente, although in 8 somewhat different connexion from its assertion in 1580 . When the king of Denmark claimed that he had dominion in the northern seas, and could, if he thought best, prohibit fishing in them vithout a licenee from him, the English envoys declared that the law of nations permitted resort and firhing in the see to all persons indifferently, that the denial of such a use of the sea by any prince was a usurpation, not a right, and that lawiol ase of the waters of the onght to be as free to all men as the air itself. They acknowledged thet juriadiction in adjacent might belong to princes hering realms adjoining, in order that navigation might be safe from pirates and enemies, bot denied any dominion over the watara. They declared that the most celebrated lawyers hed given their judgment that the eea, by the law of nations, is freo and common, and cannot be monopolised by any prince."

On atill another point of international law interesting regulations were laid down by Elisabeth's government during the latter years of her reign. In the 'Larrs and Ordinances ' issued by the earl of Leicester when he took command of the queen's foroes in the Netherlands in 1584, it is provided, "That no man in any part of this service that he shall doe shal lay violent handes upon any roman with childe, or lying in childebed, olde persons, widores, yong virgins, or babee, without especiall order from the magistrate, upon paine of death.' In the instructione given to the earl of Esser, 15 Jane 1697, as he was about to set out upon the 'Islands Voyage, are included the following humane provisions concerning the treatment of non-combatants :-

We vill and specially require you to give strayto commendment to all persons ervng ander jour aharge by or by lend, thet thare be

$"$ Cemden, Amales, il. 200, 972-8; Bgmor, Fondora, vii. pk li, 60.

- Ibidh; Oumder H 207. 
mede no vlaghtar of people, but such se shall with open foroe menifently whetand you ar our people to your and their danger, but to admit all such to mercy as all freely submitt themsalves and so detayne ruch of them as priconers to be redeemed acording as the qualities of their extate my be knowen. And likewies we doo most etraitly charge you to give utrait commandment to ell ervng in our nevy end army, apon payne of death, in no sorte to spoyle ar destroje eny church or plece eppoynted to divine ervice, nor wy hospitall uned to keepe rial ar poore people. Bat if eny of your ennemyes appoynted as men of wax or souldier shell flee to eny chareh or hoepitall to unve himself, which ume person ahall be a person worthy to be taten as a privaner, it ahell be Inwfull with foroe to reoover him, without deatroying of the ahoreh or hospitall. And likewise allo yon ahall forbid and restrayne all persons from talling or frillfull harting of eny women or ohildren, or any aged or ick person not liable to carry reapon or arme.

Similar views as to what jas justifiable and not justifiable in suoh ceses had already been stated with a wealth of quotation and illustration by Gentilie in a I Latin pork in 1588 ; but there is no indication that euch rules had been before eo clearly formulated for a practical occasion. ${ }^{10}$

Thus during the last twenty-three years of the reign of Elizabeth, in addition to some minor pointe, her government asserted consistently two important cleims in the field of international law: first, that during the progress of a mar goods carried by merchants of a nation not angaged in the war, which might aid one party, mey justly be confiscated by the other; secondly, that the sea is free, in the sense that no nation may exclude others from any large stretch of it, nor place arbitrary rostrictions upon them when nevigating it. The rimple questions involved in these principles were doubtlese much obscured by the prevalent recklessness and violence at sea. The maritime policy of the English at this time included a wide and almost andefined field of practice, ranging all the way from the simple self-defence of armed merchant veswels, through verious forms of reprisals, privateering, and seisure, to sheer bald piracy. It is not to be wondered at if other nations did not alway clearly distinguiah seirare under the claim of contraband from those frequent instances of ceptrre under some other, or no other, claim which, in the later sixteenth century, bade fair to make Engliahmen the Bcourge of the seas. When the Englimh ambassedor went to Copenhagen in 1592 " he was railed at by divers gentlemen of the conrt, who called him thief, and said that our countrymen were a company of thieves, and had robbed their ships, for which they could have neither law

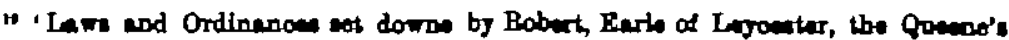
Mejenty's Lifotement and Oeptedne Generd of her armien and foroes in the Low

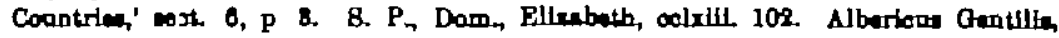
D. Iwre Ballh, lib. if. $\infty$ Irlf Ixi. 
678 INTERNATIONAL LAW UNDER ELIZABETH Oct.

nor justice.' A contemporary Germen pamphlet, in giving, ander the year 1598, an account of the actions of Elizabeth, anys, 'She prepared also in the same year certain coragirs and oea robbers upon the ocesn, who eeired many grain ship and everything they conld.' An Englishman eettled in Rouen rrites to Cecil, 19 Dec. 1602, "The better sort of Frenchmen hate as for continual com. plaints in caupes, as though our nation lived on their spoil.' to The state papers, reports of ambaseadors, and foreign correspondence are full of bitter complaints of English depredations at eea. The justice of the cleim of seixure of contraband was clonded by the manifest injustice of meny other seisures by Englishmen.

Nor was any appreciable progress made during the pariod with which we are concerned in the development of the principles nnderlyung the English claims. The arguments ueed to support them were the same at the end as at the beginning. They received no serious or extended discussion by the for writers of the time who interested themeelves in international lew. There seams to be no discussion of either contraband or the freedom of the writings of Gentilis. They were, on the other hand, a nataral and consistent part of the vigorons, direct, and practical policy of the gorernment of Queen Elisabeth. The occesion for the assertion of the freedom of the was found in the rapid extension of the sphere of England's commercial ectivity and the obstacles which the claims of other nations put in its ray. The question of seizure of contraband arose from the circumstance of a desperate war waged with a power which had, or eeemed to have, an unlimited amount of money, but which was singularly dependent on other conntries for the direct requirements of warfare.

Edward P. Chemey.

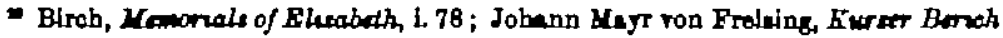
aller podenkedrdigon Sackon; Cal. of State Paperh, 1001-3, p. 200. 